\title{
寄棟屋根上に端部まで設置された太陽光発電パネルの風荷重と 屋根莫き材の風荷重低減効果

\author{
WIND LOADS OF PHOTOVOLTAIC PANELS MOUNTED ON A HIP ROOF TO THE EDGE AND \\ THEIR WIND-LOAD REDUCTION EFFECT ON ROOF CLADDING
}

山家哲生 ${ }^{* 1}$, 山本篤志*2, 植松 康*3

Tetsuo YAMBE, Atsushi YAMAMOTO and Yasushi UEMATSU

\begin{abstract}
The present paper investigates the wind loads on PV panels installed over the whole area, including the edge zones, of a hip roof in a wind tunnel. The wind pressures underneath the PV panels, called 'layer pressures', are evaluated by a numerical simulation using the unsteady Bernoulli equation together with the time history of external pressures measured at many locations on the rooftop. We propose to install PV panels with small gaps between them, which may reduce the net wind pressures on the PV panels due to pressure equalization. The wind pressures on roof cladding may be reduced too.
\end{abstract}

Keywords : Photovoltaic system, Roofing, Hip roof, Numerical simulation, Pressure equalization, Wind tunnel experiment 太陽光発電パネル，屋根草材，寄棟屋根，数值シミュレーション，等圧効果，風洞実験

\section{1. はじめに}

太陽光発電 (Photovoltaic : 以下, PV) は, 再生可能エネルギーとし て注目されており,その普及が望まれている。地上設置型に加えて, 住宅の屋根上に設置されるケースも増えており, 発電量拡大に向け た取り組みが重要な課題となっている。

現在, 住宅には切妻屋根や寄棟屋根といった勾配屋根が多く利用 されている。一般にこれら勾配屋根の外周部には流れの剥離に伴う 渦発生によって大きな負圧が作用する。それに伴い，瓦等屋根莫き 材の強風被害 (飛散)が多く報告されている ${ }^{1)} 。$ 同様に, 屋根上に設 置された PV パネルの飛散もしばしば発生している ${ }^{2)}$ 。屋根莫き材 や PV パネルが飛散すると他の建築物等に二次被害を及ぼすため, それらの耐風性向上は重要な課題である。

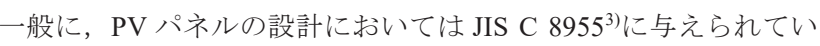
る風力係数が用いられるが, 屋根外周部には大きなピーク負圧が作 用するため，JIS C 8955 には屋根外周部(端から $30 \mathrm{~cm}$ 以内の領域)
に設置される $\mathrm{PV}$ パネルの風力係数は与えられていない。しかし， $\mathrm{PV}$ パネルの風力係数を適切に評価した上で適切な耐風設計・施工 を行えば屋根外周部にも PV パネルを設置することは可能である。

PV システムの耐風性を向上させる方法は，耐力を上げるか風荷 重を低減させるかのいずれかである。前者はコスト高を招くため, ここでは後者に着目する。具体的には, PV パネルをパネル間に隙間 を設けて設置することを提案する。すなわち，隙間による「等圧効 果」を利用することで PV パネルに作用する風力の低減を図る。こ れによって PV パネルを屋根外周部にも大きなコス卜高を伴わずに 設置することが可能となり，一棟としての発電量が増加する。加え て, 屋根莫き材に作用するピーク外圧が低減することで，屋根莫き 材の強風被害低減も期待される。

$\mathrm{PV}$ パネルに作用する風力は上下面に作用する風圧差で与えられ るが，屋根上に設置された PV パネルを建築物と同じ縮尺率で再現 し，下面の風圧を風洞実験で測定することは，模型作製上，非常に
*1 東北電力ネットワーク(株)

*2 旭化成ホームズ株

*3 独立行政法人国立高等専門学校機構秋田工業高等専門学校 校長·工博
Tohoku Electric Power Network Corporation

Asahi Kasei Homes Corporation

President, National Institute of Technology (KOSEN), Akita College, Dr.Eng. 
難しい。そこで, 本研究では風洞実験で測定した屋根面風圧 (外圧) 分布から, PV パネルの最外周位置および PV パネル間の隙間位置に おける風圧を求め, 隙間を通る流れに非定常ベルヌーイ方程式を適 用することで PV パネル下の空間の風圧 (以下,「層内圧」と呼ぶ)を シミュレーションする。この層内圧は屋根莫き材に外圧として作用 する。本研究では, まず層内圧をシミュレーションによって求める 方法を示し，簡単なモデルを用いた風洞実験によってその妥当性を 確認した上で, 寄棟屋根上に設置された $\mathrm{PV}$ パネルのピーク風力を PV パネル間の隙間の影響に着目して評価する。また, PVパネル設 置による屋根莫き材のピーク外圧低減効果も把握する。

\section{2. 対象建築物}

本研究で対象とする建築物は一般住宅を想定した寄棟屋根を有す る建築物である。また, 本研究では, 4.で述べるように, パネル裏面 圧(層内圧)を求めるために非定常ベルヌーイ方程式を応用したシミ ユレーションを用いるが, その方法の妥当性を, より単純な形状で ある軒の出のない方形屋根を有する建築物をモデル化した模型を用 いて検証する。つまり, 実験を再現したシミュレーション結果と直 接実験で得られた結果を比較する。なお,この方形屋根モデルを Model 0, 本研究の主対象である寄棟屋根モデルを Model 1 と呼ぶ。

Model 0 および Model 1 の各種寸法を Fig. 1 および 2 に示す。 Model 0 は辺長 $11 \mathrm{~m}$ の正方形平面で, 頂部高さ $10.7 \mathrm{~m}$ の方形屋根を 有する建築物で, 軒の出はなく, 屋根勾配は住宅によく用いられる $25^{\circ}$ (概ね 4 寸 5 分勾配) とし, 屋根の一面にのみ $\mathrm{PV}$ パネルが設置さ れているものとする。Model 1 は $9.4 \mathrm{~m} \times 18.6 \mathrm{~m}$ の長方形平面で棟高 $10.7 \mathrm{~m}$ の寄棟屋根を有する建築物である。軒の出は $0.9 \mathrm{~m}$, 屋根勾 配は Model 0 と同様に $25^{\circ}$ とする。

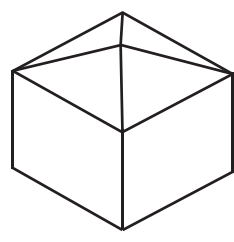

(a) Image

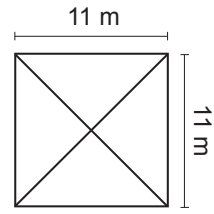

(b) Plan view

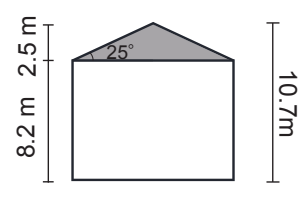

(c) Elevation
Fig. 1 Square-roof building (Model 0)

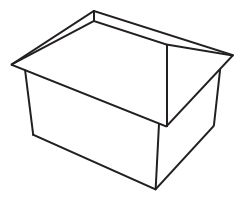

(a) Image

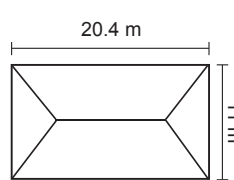

(b) Plan view

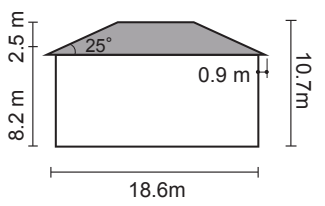

(c) Elevation
Fig. 2 Hip-roof building (Model 1)

\section{3. 風洞実験方法}

\section{1 実験模型}

模型の幾何学的縮尺率は Model 0 で $1 / 75$, Model 1 で 1/100 とす

る。Model 0 は PV パネル付きのモデルであるが，比較的形状が単純 であるため, アクリル板を用いて作製した。Model 1 は軒を有する モデルであり, やや複雑な形状であるため, 屋根部分を 3D プリン ターで，それ以外はアクリル板で作製した。
本研究では，矩形の PV パネルを屋根面いっぱいに設置するケー スを想定している。実験では実況を忠実に再現した模型を用いるの が理想であるが，模型作製上の制約もあり，Model 0 の PV パネルは 厚さ $2 \mathrm{~mm}$ のアクリル板で再現し，当該板の下面と屋根面との隙間 は $1 \mathrm{~mm}$ とした。これらの数值は実システムでの寸法よりいくらか 大きいが，既往の研究で勾配屋根に設置された PV パネルの風力係 数を検討した高森らの論文 ${ }^{4)}$ と同様である。また，PVパネルは一般 にレールによって支持されるが，ここでは施工性を考慮し，レール は水平方向に設置されるものとした。このレールは, PVパネル裏面 の風圧分布に影響すると考えられるので，風洞模型でもレールをモ デル化して再現した。具体的には，レールの高さを $0.5 \mathrm{~mm}$ (実スケ ールで $37.5 \mathrm{~mm}$ )，レールと屋根面との隙間を $0.5 \mathrm{~mm}$ とした。 $\mathrm{PV}$ パ ネルの配置と屋根面の一部の断面図を Fig. 3 に示す。レール位置お よびパネル間の隙間は Fig. 3 (a)に示すとおりである。
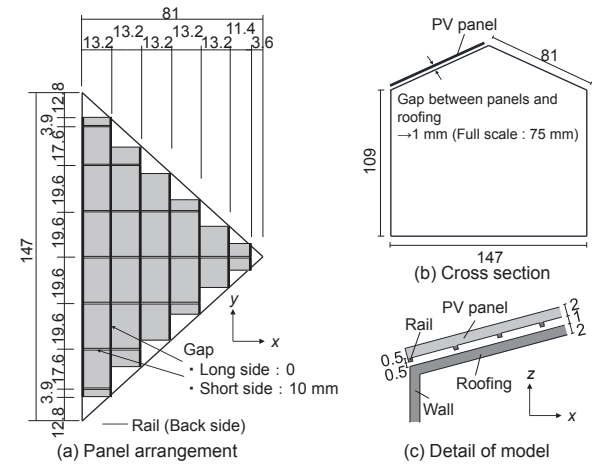

(c) Detail of model

Fig. 3 Installation position of PV panels (Square roof)

Fig. 4 および Fig. 5 は，方形屋根モデル (Model 0) および寄棟屋根 モデル (Model 1) におけりる風圧測定孔 ( $\phi 1 \mathrm{~mm})$ 配置を示す。Model 1 に おいて三角形の屋根面をRoof A, 台形の屋根面を Roof B と呼ぶ(Fig. 5)。本検討においては PV パネルを南面や東西面に設置することを 想定し， Roof A と Roof B の 2 面を対象とする。いずれのモデルで も圧力測定孔は大きな負圧が作用すると考えられる屋根外周部に多 く配置されている。なお，Fig. 4 (Model 0) では屋根面上および PV パ ネル面上の圧力測定孔位置を示している。PV パネルに作用する風 力を求めるにはパネル上下面の風圧を測定する必要があるが, 下面 風圧を測定することは模型作製上困難であるため, 屋根面風圧を $\mathrm{PV}$ パネルの下面風圧として代用する。

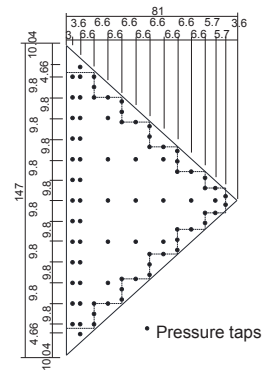

(a) Roof

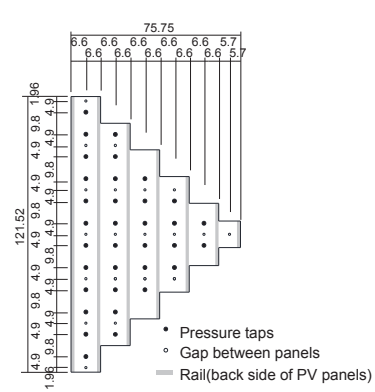

(b) PV panel
Fig. 4 Layout of pressure taps (Model 0) 


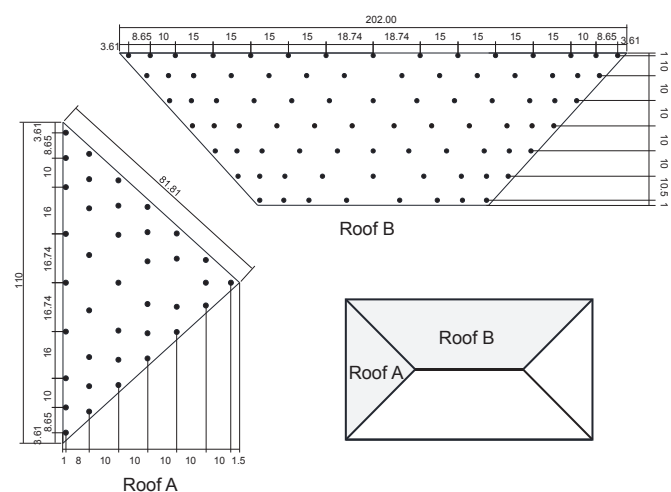

Fig. 5 Layout of pressure taps (Model 1)

Model 0 において, PV パネル間には短辺方向に $10 \mathrm{~mm}$ (実寸)の隙 間を想定するが (Fig. 4), この隙間を 1/75 の幾何学的縮尺率で再現 することは不可能であるため, 直径 $1 \mathrm{~mm}$ の円形孔で置き換える (Fig 6)。なお, 円形孔は PV パネル間の隙間の中心位置に設置され，孔 の面積は概㸚隙間面積と等しい。

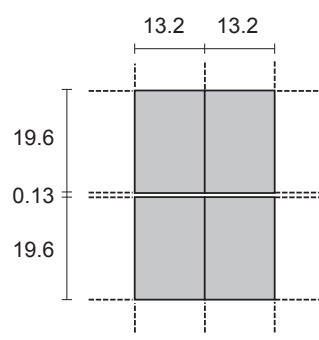

Actual gap

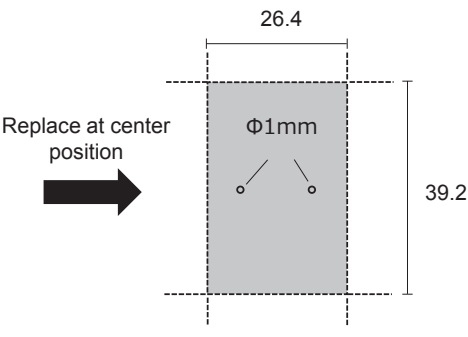

Deformed gap
Fig. 6 Modeling of the gap between PV panels

\section{2 実験気流}

本研究では, 実験に東北大学大学院工学研究科都市・建築学専攻 所有のエッフェル型境界層風洞を使用した。Fig. 7 (a) に本実験で使 用した気流のプロファイルを示す。実験気流は, 平均風速のプロフ アイルを表す「べき指数」 $\alpha$ が約 0.27 , 模型屋根平均高さにおける 乱れの強さ $I_{H}$ が約 0.17 の境界層乱流である。 $\alpha$ は建築物荷重指針・ 同解説 ${ }^{5)}$ (以下，「荷重指針」と呼ぶ) における地表面粗度区分IVの 值に近い。一方， $I_{H}$ は地表面粗度区分III の值に近い。低層建築物に 作用する風圧の特性については, べき指数 $\alpha$ の影響は小さく, 乱れ の強さ $I_{H}$ の影響が大きいと言われているの。したがって, 本実験結 果はターゲットとしている地表面粗度区分III相当の気流中での結果 に概ね相当するといえる。Fig. 7(b) は実スケールで高さ $z=10 \mathrm{~m}$ (縮 尺率 $1 / 100$ と仮定) における風速変動のパワースペクトル密度 $S_{u}(f)$ をカルマン型と比較したものであり, 両者はよく一致している。こ の高さ(ほぼ屋根平均高さ)での乱れのスケール(積分スケール) $L_{x}$ は約 $0.2 \mathrm{~m}$ である。低層建築物に作用する風圧性状に及ぼす乱れの スケールの影響を検討した Tieleman らフによれば, 風洞気流の $L_{x}$ の 值が自然風に対する目標値の 0.2 倍程度より大きく, かつ，模型の 最大長さ以上であれば，風圧に及ぼす $L_{x}$ の影響が小さい。高さ $10 \mathrm{~m}$ での $L_{x}$ は荷重指針 ${ }^{5}$ より $57.7 \mathrm{~m}$ と計算され，縮尺率 $1 / 100$ の場合 $0.577 \mathrm{~m}$ (その 0.2 倍は $0.115 \mathrm{~m}$ ) となる。また，模型の最大長さは 0.2 $\mathrm{m}$ 程度である。したがって, 風洞気流の $L_{x}$ は上記の条件を概ね満た
している。さらに, Tieleman ${ }^{8}$ は, 低層建築物の場合, 式(1)で定義さ れる Small scale turbulence parameter $S$ が重要な役割を果たすとし, 変動風圧に及ぼす $S$ の影響は $S \approx 300$ までは大きいが $S>300$ では小 さいことを示した。本実験気流での $S$ を求めると約 470 であり, 変 動風圧が $S$ の影響をほとんど受けない領域 $(S>300)$ に入っている。

以上より，風洞気流は実験気流として妥当であると判断する。

$$
S=\frac{n_{s} S_{u}\left(n_{s}\right)}{\sigma_{u}}\left(\frac{\sigma_{u}}{U}\right)^{2} \times 10^{6} \quad \text { ただし } n_{s}=\frac{10 U}{L_{B}}
$$

ここで， $\sigma_{u}$ は変動風速の標準偏差， $U$ は平均風速， $L_{B}$ は構造物の代 表寸法を表す。

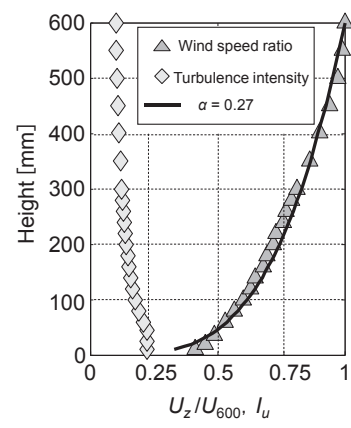

(a) Profile

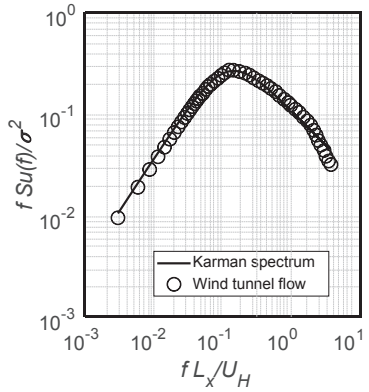

(b) Power spectrum
Fig. 7 Characteristics of wind tunnel flow

\section{3 風圧測定方法}

設計風速は，特に強い風が吹く南西諸島や沿岸部等を除く地域に おける代表的な值として荷重指針での基本風速 $U_{0}$ を $35 \mathrm{~m} / \mathrm{s}$ と仮定 する。地表面粗度区分をIII と仮定すると，屋根平均高さ $H$ における 設計風速 $U_{H_{-} \text {full-scale }}$ は $27.8 \mathrm{~m} / \mathrm{s}$ と計算される ${ }^{5)}$ 。実験風速 $U_{H_{-} \text {model-scale }}$ は屋根平均高さで $8 \mathrm{~m} / \mathrm{s}$ とした。この場合, 風速の縮尺率は $1 / 3.5$ と なり, 時間の縮尺率は, 幾何学的縮尺率 $1 / 75$ の場合 $1 / 21$, 幾何学的 縮尺率 1/100 の場合 $1 / 29$ となる。風向 $\theta$ は, Fig. 8 およびFig. 9 に示 すように定義し, モデルの対称性を考慮し, Model 0 では $0^{\circ}$ から $180^{\circ}$ の範囲を $15^{\circ}$ 刻みで変化させた。一方, Model 1 では $0^{\circ}$ から $360^{\circ}$ の 範囲を 5 刻みで変化させた。圧力測定孔に作用する風圧は，サンプ リング周波数 $800 \mathrm{~Hz}$ で全点同時測定し, 実大スケールで 600 秒のデ 一タを 10 組取得した。計測時における高周波数帯域のノイズを除 去するため, $300 \mathrm{~Hz}$ のアナログローパスフィルターを使用した。ま た，チュービングによる変動風圧のゆがみの補正は計測システムの 周波数応答関数を用いて周波数領域で行った。

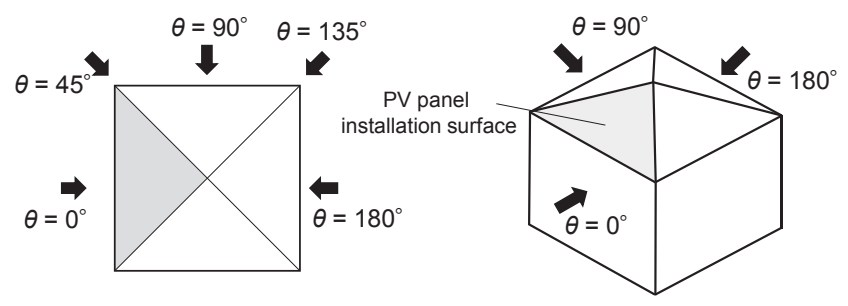

Fig. 8 Definition of wind direction (Model 0) 


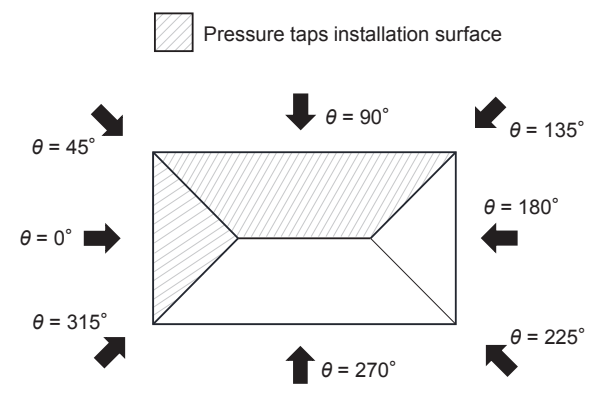

Fig. 9 Definition of wind direction (Model 1)

\section{4 データ解析方法}

風洞実験で得られた圧力 $P_{e}$ と風洞内静圧 $P_{s}$ の差を模型屋根平均 高さ $H$ における速度圧 $q_{H}$ で無次元化し, 次式で定義される風圧係 数 $C_{p e}$ で表す。

$$
C_{p e}=\frac{P_{e}-P_{s}}{q_{H}}
$$

風圧係数や以下に示寸風力係数の平均值や最大 - 最小ピーク值等, 各種統計量の評価時間は実大スケールで 600 秒とし, それぞれ 10 組 のデータに対するアンサンブル平均で評価する。また, ピーク值は 最近の外装材の風荷重を扱った研究で一般的な 0.2 秒の平均時間 (実大スケール)で評価する。この平均化時間は，代表的な值として 変動風圧のディケイファクター $k=6$, 部材長さ $\Delta=1 \mathrm{~m}, U_{H}=25 \mathrm{~m} / \mathrm{s}$ と おき，TVL 法に基づき算定された值である ${ }^{9)}$

\section{PV パネル裏面圧のシミュレーション}

\section{1 シミュレーション方法}

PV パネル下の空間を「仮想室」と定義したいくつかの空間に分割 する。隣り合う仮想室相互, もしくは仮想室と外部との空気の出入 りに着目し，数值解析的に層内圧を計算する。隣り合う仮想室間の 境界面, 仮想室と外部との隙間, 並びに PV パネル間の隙間を通る 流れに, Oh et al. ${ }^{10)}$ にり提案され, 渡部・植松 ${ }^{11)}$ が通気層工法の層 内圧推定に使用した式を $x, y, z$ 軸方向それぞれに適用する ((3) (5) 式。座標軸については Fig. 3 参照。 $z$ 軸は上向き正)。シミュレーシ ヨンでは PV パネルの最外周位置およびパネル間の隙間位置におけ る外圧係数が必要になるが, それら全てを風洞実験で直接測定する ことは難しい。そこで, それらは実験データ(風圧測定孔での值)に 3 次スプライン関数を用いた空間補間を適用して算出する。

$$
\begin{gathered}
\frac{\rho l_{i, j} \dot{U}_{i, j+1}}{q_{H}}=C_{i, j}-C_{i, j+1}-\left.\frac{1}{2 q_{H}} C_{L} \rho_{i, j} U_{i, j+1}\right|_{i, j} U_{i, j+1} \mid-\frac{\Delta p_{x}}{q_{H}} \\
\frac{\rho l_{i, j} \dot{U}_{i+1, j}}{q_{H}}=C_{i, j}-C_{i+1, j}-\frac{1}{2 q_{H}} C_{L} \rho_{i, j} U_{i+1, j}||_{i, j} U_{i+1, j} \mid-\frac{\Delta p_{y}}{q_{H}} \\
\frac{\rho l_{\mathrm{e}} \dot{U}_{i, j}}{q_{H}}=C_{i, j}-{ }_{\mathrm{e}} C_{i, j}-\frac{1}{2 q_{H}} C_{\mathrm{Le}} \rho_{\mathrm{e}} U_{i, j}\left|U_{\mathrm{e}} U_{i, j}\right|-\frac{\Delta p_{\mathrm{e}}}{q_{H}}
\end{gathered}
$$

ここで，下付き添え字の $i, j$ は仮想室番号を表し，それぞれ行 $(x$ 方 向）と列 $(y$ 方向）を表す。Fig. 10 のように各仮想室を「Room」と表 ᄂ, Room 1 を 1 行 1 列目 $(i=1, j=1), \operatorname{Room} 2$ を 1 行 2 列目 $(i=1, j$ =2) とする (以下, 同様)。なお, 隣接する室がない場合（仮想室が 外周部に接する場合）は当該仮想室の外側の辺の中心位置における 外圧を用いて仮想室内の内圧の時間変化量を計算する。Uは左右の
下付き添え字で表される仮想室 (ただし,$e$ は外部)間を流れる隙間 流れの流速 $[\mathrm{m} / \mathrm{s}], q_{H}$ は速度圧 $[\mathrm{Pa}], \rho$ は空気密度 $\left[\mathrm{kg} / \mathrm{m}^{3}\right], l$ は隙間 の深さ $[\mathrm{m}], e_{e} C$ は外圧係数 $[-], C$ は (2) 式と同様に定義される層内 圧係数 $[-], C_{L}$ は水平 $(x, y$ 軸 $)$ 方向の形状抵抗係数 $[-], C_{L e}$ は鉛直 $(z$ 軸) 方向の形状抵抗係数 $[-], \Delta p$ は各軸方向 (ただし, $e$ は外部)の摩 擦による圧力損失 $[\mathrm{Pa}]$ を表し, 次式で与えられる。

$$
\Delta p=\lambda \frac{l_{e}}{D_{e}} \frac{\rho}{2} U_{i, j}\left|U_{i, j}\right|
$$

ここに, $\lambda$ は摩擦抵抗係数 $[-], l_{e}$ は隙間の深さ $[\mathrm{m}], D_{e}$ は隙間幅 $[\mathrm{m}], U_{i, j}$ は仮想室 $(i, j)$ を通る空気の流速 $[\mathrm{m} / \mathrm{s}]$ を表す。 $\mathrm{PV}$ パネル

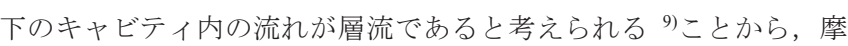
擦抵抗係数中の隙間流れにおける定数項は 64 と仮定する。また, 隙 間深さ $l_{e}$ は隙間の面積を考慮した有効深さを用いる ${ }^{10)}$ 。なお，本研 究においては PV パネルのフレーム (側面)の形状までは考慮せず, 抵抗が比較的小さい形状として流量係数 1.0 の隙間と設定した（そ の場合, 形状抵抗係数も約 1.0 となる)。ここでは計算負荷を考慮し 陽解法の 4th-Order Runge-Kutta 法を用い, 時々刻々の流速や外圧係 数を上記(3) (5) 式に代入して, 流速の時間変化量を求める。そして, 得られた值を内圧の時間変化を表す(7)式に代入して仮想室内の圧 力を求める。時間刻みは, 計算が発散しない值として, 1/8000 秒と する。

$$
\frac{d P}{d t}=\frac{\gamma P_{0}}{V_{0}} \sum Q
$$

ここで, $\gamma$ は比熱比 $[-], P_{0}$ は大気圧 $[\mathrm{Pa}], V_{0}$ は仮想室容積 $\left[\mathrm{m}^{3}\right], Q$ は 流量 $\left[\mathrm{m}^{3} / \mathrm{s}\right]$ を表す。なお， $\gamma$ は 1.4 とする。最後に内圧の時間変化量 を使って Eular 法で次ステップの層内圧係数を算出する。こうして 計算された層内圧が PV パネルの裏面圧および PV パネル下の屋根 莫き材の外圧となる。

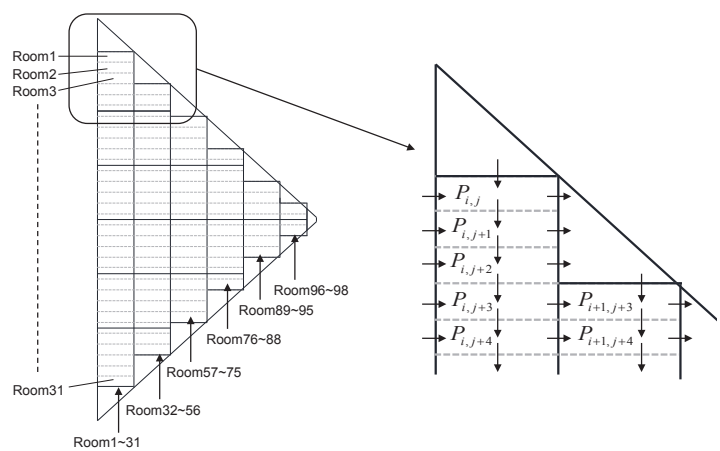

Fig. 10 Definition of virtual rooms

\section{2 解析モデル}

$\mathrm{PV}$ パネルの風力係数 $C_{f}$ は, 次式に示すように, 外圧係数（表面 の風圧係数） $C_{p e}$ と層内圧係数（裏面の風圧係数） $C_{p i}$ の差で与えら れる。

$$
C_{f}=C_{p e}-C_{p i}
$$

したがって, 非定常ベルヌーイ方程式を用いたシミュレーションに より層内圧係数 $C_{p i}$ を算出した後, 風洞実験で求めた外圧係数 $C_{p e}$ と の差をとることで PV パネルの風力係数が得られる。次に, JIS C $8955^{3)}$ と同様に，各パネルに対する面平均風力係数を各パネルに含 
まれる仮想室の面積比を用いて算定する。

\section{3 シミュレーション方法の妥当性検証}

Model 0 を用いた実験で計測された PV パネル裏面圧を上記の数 值シミュレーションによる結果と比較することで，シミュレーショ ン方法の妥当性を検証する。 Model 0 では PV パネルが 26 枚あり, Fig. 11 のように PV パネル間の隙間が 20 個あるケースを想定して いる。前述のように，スリット状の隙間は概ね等しい面積の円形孔 で置き換えている。以下，上記の方法によって計算された層内圧係 数の平均值と最小ピーク值を実験結果と比較する。

Fig. 12 に代表的な風向 $\left(0^{\circ}, 45^{\circ}, 90^{\circ}\right)$ における平均層内圧係数分 布を示す。また，それぞれの風向に対して，各測定孔位置における 層内圧係数の平均值および最小ピーク值を Fig. 13 (a)，（b)に示す。 Fig. 12 のコンター図より，実験およびシミュレーションによる平均 層内圧係数分布は概ね一致しており, Fig. 13 より平均值だけでなく ピーク值についても定量的に良い対応を示していることが分かる。 ただし，比較的大きな負圧が作用する風向 $0 \circ$ ではシミュレーション 結果はピーク值を実験值より 0.5 程度過大評価する傾向にある。そ の原因としては, シミュレーションの入力值(風圧時刻歴)において, 風洞実験の測定孔で補えない部分に 3 次スプライン関数を使って補 間 (一部外挿) していること等が挙げられる。以上より, 本研究で用 いる層内圧シミュレーション方法は妥当であると判断する。

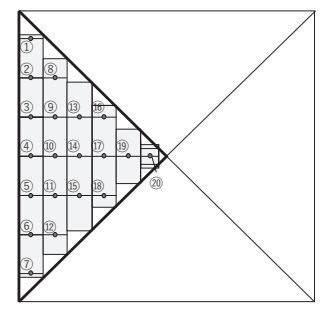

(a) Tap number

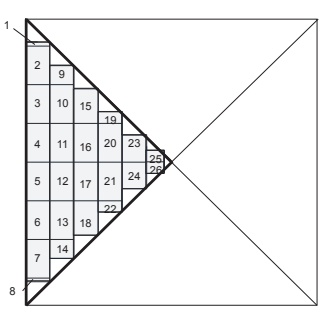

(b) Panel number
Fig. 11 Tap and panel numbers

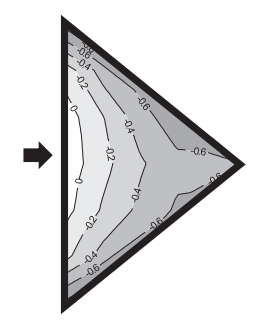

(a-1) Experiment $\left(\theta=0^{\circ}\right)$

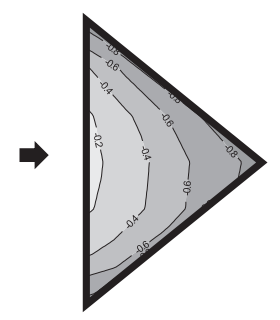

(b-1) Simulation $\left(\theta=0^{\circ}\right)$

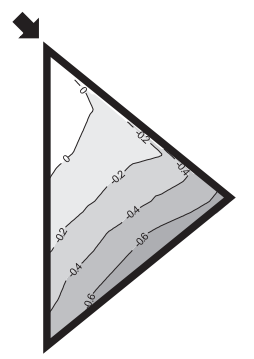

(a-2) Experiment $\left(\theta=45^{\circ}\right)$

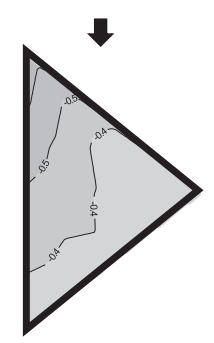

(a-3) Experiment $\left(\theta=90^{\circ}\right)$

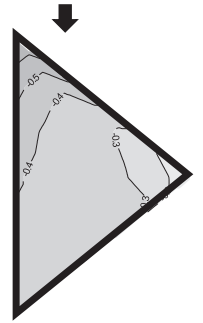

Fig. 12 Distribution of mean layer pressure coefficients
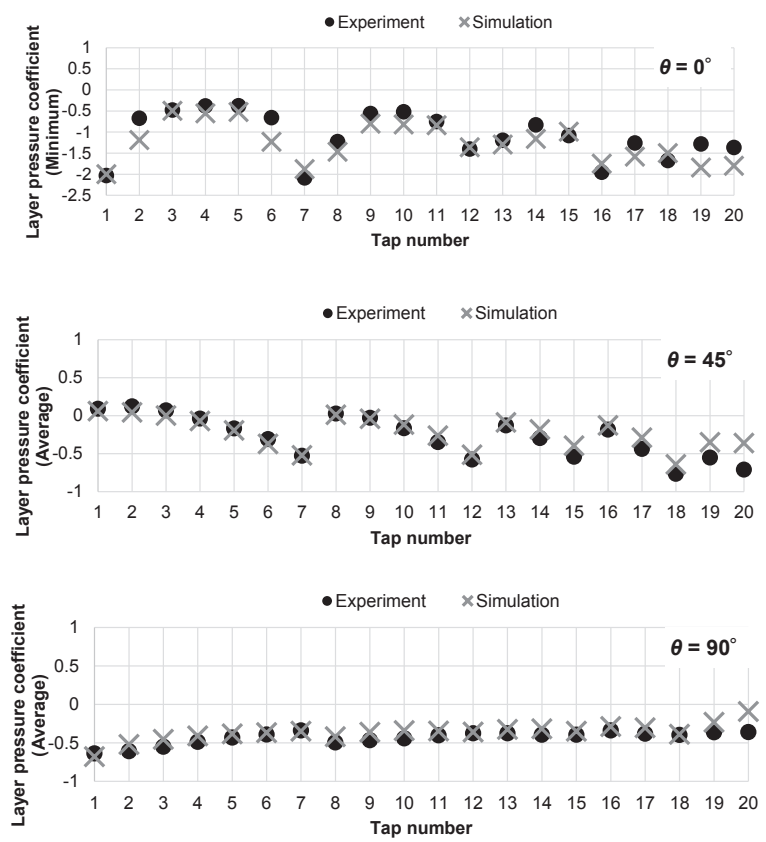

(a) Mean pressure coefficient
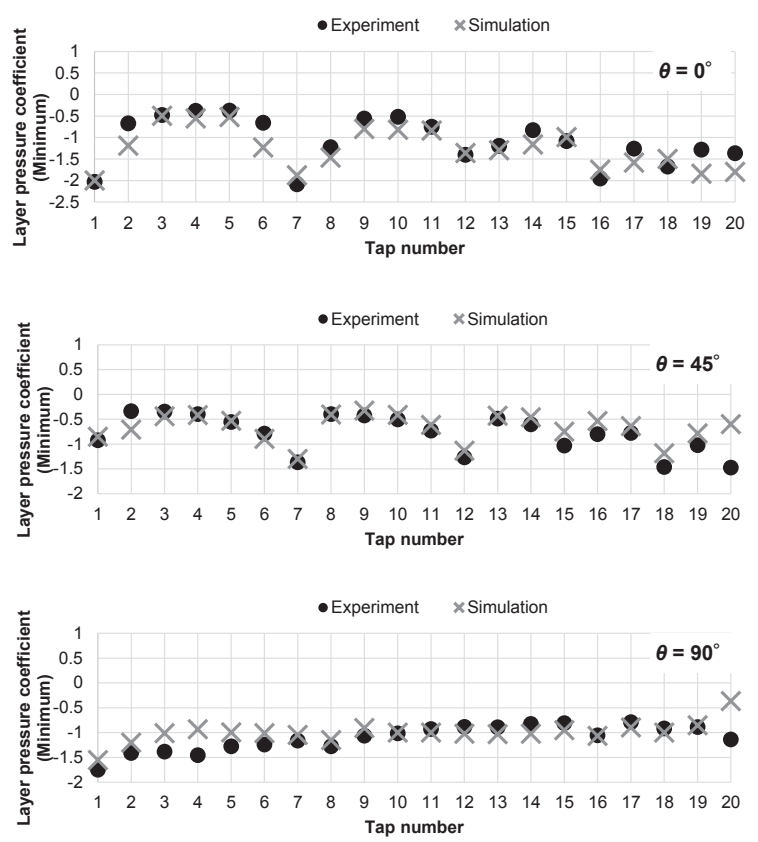

(b) Minimum peak pressure coefficient

Fig. 13 Comparison between simulation and experiment for the layer pressure coefficients 
5. 寄棟屋根面および屋根上設置 $\mathrm{PV}$ パネルに作用する風圧 · 風力

\section{1 寄棟屋根に作用する外圧分布の特徵}

ここでは，まず一般住宅を想定した寄棟屋根上に設置される PV

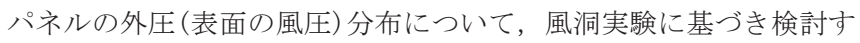
る。Fig. 14(a)〜 (c) は, いくつかの代表的な風向について, 最小ピー ク外圧係数分布を示す。なお, ここに示した值は, 10 回の測定結果 のアンサンブル平均值であり, 同時性はない。 $\theta=0^{\circ}$ や $90^{\circ}$ といった 壁面に正対寸る風向のとき, 風上の屋根外周部で大きなピーク負圧 が作用している。これは風上端での流れの剥離に伴う渦発生による ものである。一方， $\theta=45^{\circ}$ のきには風下側の隅棟部に沿って大き な負圧が作用している。これは軒先での流れの剥離に加え, 隅棟に よる収束効果が同時に発生していることによると考えられる。

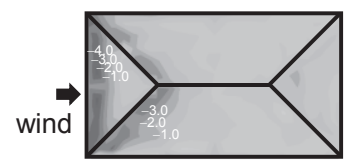

(a) $\theta=0^{\circ}$

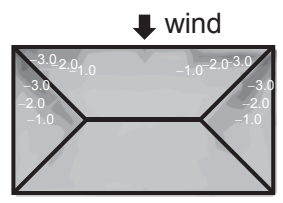

(c) $\theta=90^{\circ}$

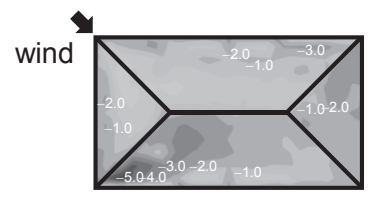

(b) $\theta=45^{\circ}$

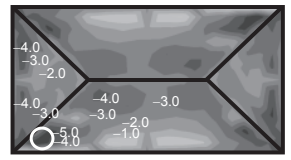

(d) All wind directions
Fig. 14 Distribution of negative peak pressure coefficients

なお，風向 $0^{\circ} や 90^{\circ}$ のき分布が左右対称になっていないのは，実 験気流の流れ直交方向の非一様性や実験模型の作製および設置精度 によるものと考えられる。次に, 測定点ごとに求めた全風向中最小 ピーク外圧係数の分布を Fig. 14 (d) に示す。絶対值が最大のものは $\theta$ $=35^{\circ}$ において -5.08 であり, 図中の白丸で示した点で発生した。

\section{$5.2 \mathrm{PV}$ パネルに作用する風力}

4.に示した手法で Model 1 の屋根上に設置された PV パネルの風 力係数を計算する。なお，ここでは PV パネルを Roof A に設置する ケースを想定し, その設置位置や枚数等は Fig. 11 (b) と同様とする。

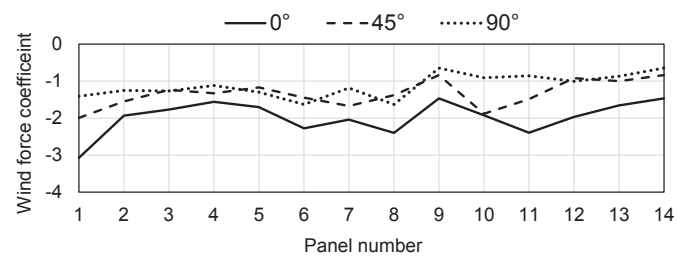

(a) Panel $1 \sim 14$

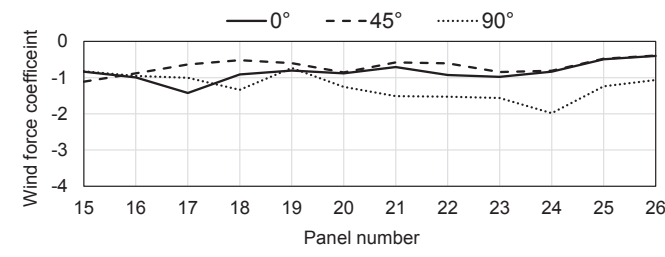

(b) Panel 15 26

Fig. 15 Negative peak wind force coefficients
また，PV パネル間には，代表的な值として $5 \mathrm{~mm}$ の隙間(短辺方向 のみ) を設ける。以下, 設計上クリティカルとなる鉛直上向きの力（負 の值) に着目寸る。代表風向 $\left(0^{\circ}, 45^{\circ}, 90^{\circ}\right)$ における負のピーク風力 係数を Fig. 15 に示す。Fig. 15 の横軸はパネル番号で縦軸はピーク 風力係数を示している。全風向, 全パネル中の最小ピーク風力係数 は Roof A の隅角部の Panel 1 において風向 $0^{\circ}$ のき発生し, その值 は-3.0であった。

次に, JIS C 8955 に記載されている風力係数との比較を行う。な お，JIS C 8955 に規定されている風力係数はピーク風力係数をガス 卜影響係数で除した「等価静的風力係数」であり, その風力係数は, 屋根外周部(軒, けらばおよび棟から $30 \mathrm{~cm}$ までの範囲)に設置され る PV パネルに対しては適用外となっている。

JIS C 8955 では勾配屋根上に設置される PV パネルの風力係数 (負 圧) $C_{a}$ は屋根勾配 $\beta$ （JIS では $\theta$ で表現）を用いて次式で与えられる。 なお，鉛直上向きを正としている。

$$
C_{a}=1.5-0.015 \beta
$$

上式に Model 1 の屋根勾配 $\left(\fallingdotseq 25^{\circ}\right)$ を代入すると, $C_{a}=1.13$ と計算さ れる。これにガスト影響係数を乗じると, ピーク風力係数は約 2.8 と なる。なお, ガス卜影響係数は, 地表面粗度区分 III で建物高さが 10 $\mathrm{m}$ の場合の数值である 2.5 とする。したがって，上述のシミュレー ションで得られた最小ピーク風力係数 $(-3.0)$ の絶対值は JIS C 8955 の值より 7\%程度大きいことが分かる。ただし，前述のように，JIS $\mathrm{C} 8955$ の風力係数は屋根外周部より $30 \mathrm{~cm}$ 内側に入った領域の $\mathrm{PV}$ パネルに対する值であるのに対し，本シミュレーションの結果は屋 根外周部に設置された PV パネルに対する值であるため, 厳密には 直接比較できるものではない。

次に, PV パネルの短辺方向に隙間を設けた場合について, 隙間幅 が PV パネルのピーク風力係数に及ぼす影響を, Roof A のパネルを 対象に検討寸る。Fig. 16 は, 軒先側が風上となる風向 0 ににおいて, 短辺方向の隙間幅を $1 \mathrm{~mm} \sim 5 \mathrm{~mm}$ の範囲で変化させたときの最小ピ ーク風力係数の変化を示寸。横軸は Fig. 11 に示した PV パネル番号 である。なお，PV パネル番号 15 以降の結果も同様の傾向を示した ため, ここでは負圧がクリティカルとなる軒先付近 (PV パネル番号 1〜14)の結果のみ示した。また, 長辺方向の隙間幅は $0 \mathrm{~mm}$ として いる。隙間幅 $1 \mathrm{~mm}$ の場合, ピーク風力係数の絶対值が最も大きく, 隙間幅を大きくすると, ピーク值の絶対值が小さくなる傾向にある。 なお，結果は示していないが，隙間幅を $5 \mathrm{~mm}$ より大きくしても 5 $\mathrm{mm}$ の場合の結果とほとんど差がないことが分かった。したがって， 風力低減の観点からは隙間幅として $5 \mathrm{~mm}$ 程度が最適值と考えられ る。また，紙面の都合上結果は示さないが，Roof B についても以上 示した Roof A と同様の結果が得られた。

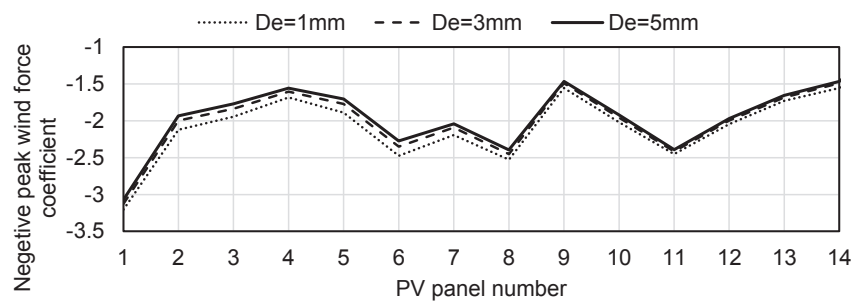

Fig. 16 Negative peak wind force coefficients for various gap widths 


\section{$5.3 \mathrm{PV}$ パネルによる屋根風荷重低減効果}

ここでは，PV パネル設置による屋根葺き材の風荷重低減効果に ついて検討する。屋根莫き材に作用する風力は，外圧と裏面圧との 差で与えられるが, 裹面圧は屋根構法や屋根莫き材の影響を強く受 けるため, 一律に評価することは難しい。そこで, 簡単のため裏面 圧を 0 と仮定すると, PV パネルがない場合, 風力は外圧と等しくな る。一方, PV パネルを設けた場合, 層内圧が屋根莫き材の風力とな る。Fig. 17 は, 風向 $\theta=0^{\circ}, 45^{\circ}, 90^{\circ}$ の場合について, PV パネルが ない場合の外圧係数と PV パネルを設置したときの層内圧係数の最 小ピーク值を比較したものである。ここで, PV パネル間の隙間は 5 $\mathrm{mm}$ としている。図の横軸は仮想室番号 (Fig. 10 参照)を表している が, ここでは Roof A において大きな負圧が作用する軒先の領域の結 果 (Room 1〜31) のみ示した。図中の実線が外圧係数 (PV パネルを設 置しない場合の屋根莫き材の風力係数と等価), 破線が層内圧係数 (PV パネルを設けた場合の屋根莫き材の風力係数と等価) の最小ピ 一ク值を表している。これより, PV パネルを設けた場合の風力係数 の絶対值が全体的にかなり小さくなっており, PV パネルを設置す ることによる屋根莫き材の風荷重低減効果が期待される。また, 紙 面の都合上結果は示さないが, Roof B についても Roof A と同様に 屋根莫き材の風力が大きく低減されるという結果が得られている。

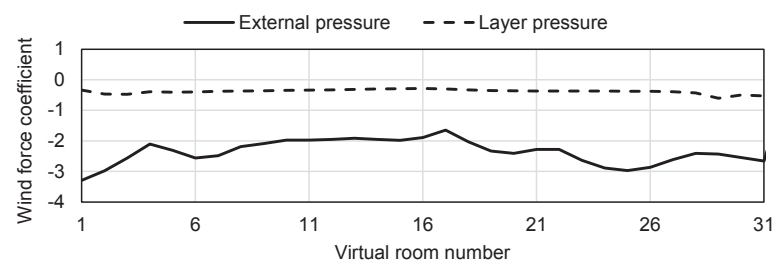

(a) $\theta=0^{\circ}$

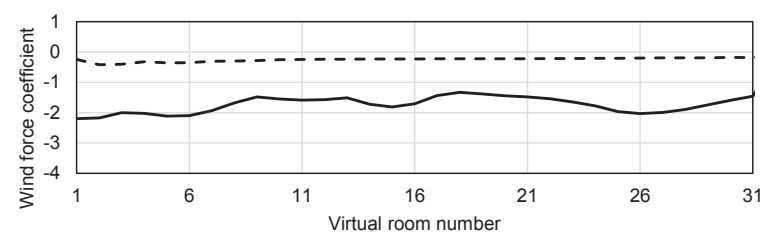

(b) $\theta=45^{\circ}$

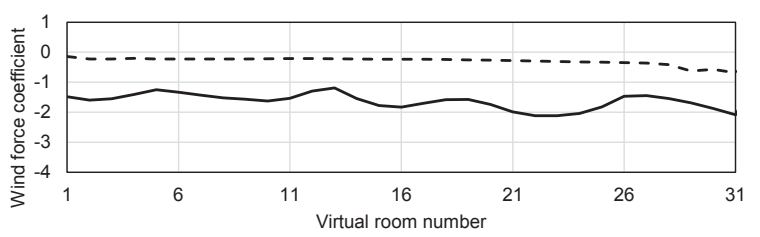

(c) $\theta=90^{\circ}$

Fig. 17 External pressure and layer pressure

\section{6. 結論}

寄棟屋根上に設置される $\mathrm{PV}$ パネルの風力係数および屋根莫き材 の外圧係数について, 風洞実験並びに数值シミュレーションに基づ き検討した。層内圧のシミュレーション方法の妥当性は, 単純な方 形屋根建築物の模型を用いた風洞実験結果とシミュレーション結果 との比較により確認した。次に，そのシミュレーションに基づき， 寄棟屋根のほぼ全体に設置された PV パネルの風力係数を求めた。 このピーク風力係数は, 流れの剥離によって大きなピーク負圧が作 用寸る屋根外周部で大きくなるが，PV パネル間に $5 \mathrm{~mm}$ 程度の隙間 を設けることで低減され，JIS C 8955 に規定される風力係数の最大 值より $7 \%$ 程度大きな值であった。また, PV パネルを設置した場合, 層内圧が屋根莫き材に作用寸る外圧となるが，その大きさは PV パ ネルを設置しない場合の外圧よりかなり小さくなることが示され， $\mathrm{PV}$ パネルを設置することによる外装材の風荷重低減が期待される。

\section{参考文献}

1) Kobayashi, F. et al.: Immediate report on wind disasters occurred by Typhoon 1915 , Wind Engineers, JAWE, Vol. 45, No. 1, pp.30-39, 2020.1

小林文明ほか：【速報】台風 1915 号(FAXAI)がもたらした強風被害につい て, 日本風工学会誌, 第 45 巻, 第 1 号, pp.30-39, 2020.1

2) Koji Takamori: Factual situation of strong wind damage on photovoltaic systems and background on creating the manual of wind resistant, Wind Engineers, JAWE, Vol. 43, No. 2, pp.103-108, 2018.4

高森 浩治: 太陽光発電システムの強風被害の実情と而風設計マニュアル作 成の背景, 風工学会誌, 第 43 巻, 第 2 号 pp. 103-108, 2018.4

3) JIS C 8955: Load design guide on structures for photovoltaic array, 2017 JIS C 8955 : 太陽電池アレイ用支持物の設計用荷重算出方法, 2017

4) Koji Takamori, Naohiro Nakagawa, Manabu Yamamoto, Yasuo Okuda, Tetsuro Taniguchi, Osamu Nakamura: Study on design force coefficients for photovoltaic modules installed on low-rise building, AIJ Journal of Technology and Design, Vol. 21, No. 47, pp.67-70, 2015.2

高森浩治，中川尚大，山本学，奥田泰雄，谷口徹郎，中村修 : 低層住宅に設 置される太陽電池モジュールの設計用風力係数に関する検討, 日本建築学 会技術報告集，第 21 巻，第 47 号，pp. 67-70，2015.2

5) Architectural Institute of Japan: Recommendations for Loads on Buildings, 2015 日本建築学会 : 建築物荷重指針・同解説, 2015

6) Tieleman, H.W., Akins, R.E., Sparks, P.R. : A comparison of wind-tunnel and fullscale wind pressure measurements on low-rise structures, Journal of Wind Engineering and Industrial Aerodynamics, Vol. 8, pp.3-19, 1981

7) Tieleman, H.W., Hajj, M.R., Reinhold, T.A. : Wind tunnel simulation requirements to assess wind loads on low-rise buildings, Journal of Wind Engineering and Industrial Aerodynamics, Vol. 74-76, pp.675-685, 1998

8) Tieleman, H.W.: Pressures on surface-mounted prisms: the effects of incident turbulence, Journal of Wind Engineering and Industrial Aerodynamics, Vol. 49, pp. $289-300,1993$

9) Architectural Institute of Japan: Structural design concepts for earthquake and wind, 1999. 5

日本建築学会 : 動的外乱に対する設計一現状と展望一, 1999.5

10)Oh, J.H., Kopp, G.A., Inculet, D.R.: The UWO contribution to the NIST aerodynamic database for wind loads on low buildings: Part3. Internal pressures, Journal of Wind Engineering and Industrial Aerodynamics, Vol. 95, pp.755-799, 2007

11)Watanabe, K., Uematsu, Y.: Evaluation of wind loads on ventilated exterior wall systems, Journal of Wind Engineering, JAWE, Vol. 44, No. 2, pp.23-32. 2019 渡部慶, 植松康 : 通気工法を用いた外壁システムの風荷重評価に関する研 究, 日本風工学会論文集, 第 44 巻, 第 2 号, pp.23-32, 2019 
WIND LOADS OF PHOTOVOLTAIC PANELS MOUNTED ON A HIP ROOF TO THE EDGE AND THEIR WIND-LOAD REDUCTION EFFECT ON ROOF CLADDING

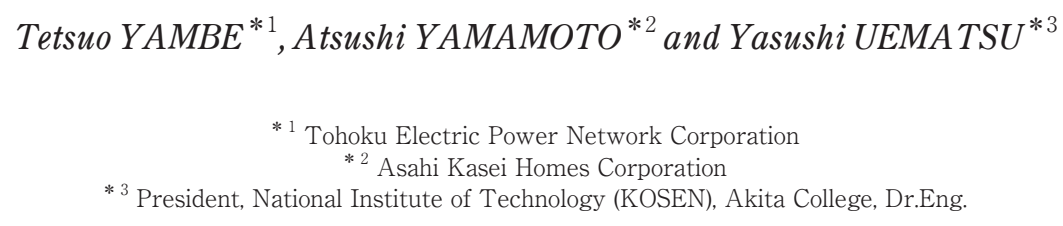

The PV systems are generally designed based on JIS C 8955 in Japan. However, no provision is given to the PV panels installed in the edge zones. It is not recommended to install them in such zones, because very large suctions are induced by flow separation. When installing PV panels in such zones, we have to evaluate the wind force coefficients appropriately. Because it is difficult to make wind tunnel models of the PV panels with the same geometric scale as that for the building, we apply a numerical simulation to evaluate the net wind forces on the PV panels, where the pressures beneath the PV panels, called 'layer pressures', are numerically simulated using the unsteady Bernoulli equation together with the time history of external pressures on the roof measured in a wind tunnel. Furthermore, we propose to install the PV panels with small gaps between them, which may reduce the net wind forces acting on the PV panels due to pressure equalization. It is expected that the external pressures on the roofing are also reduced significantly.

The present paper consists of six sections. Following the introduction, Section 2 illustrates the building models under consideration. Two models are used; one is a square-roof building with a square plan of $11 \mathrm{~m} \times 11 \mathrm{~m}$ and the other is a hip-roof building with a rectangular plan of $18.6 \mathrm{~m} \times 9.4$ $\mathrm{m}$. The ridge height and the roof slope are respectively $10.7 \mathrm{~m}$ and approximately $25^{\circ}$ in both models. Section 3 describes the experimental models and procedure used in the wind tunnel experiment. In the square-roof model case the PV panels installed on the roof are also modeled. The wind pressures at many locations on the top surface of PV panels as well as on the roof surface are measured in a wind tunnel, the results of which are used for validating the simulation method of layer pressures. The hip-roof model is not equipped with PV panels. The wind pressures measured on the roof are used for simulating the layer pressures. Section 4 first explains the method of simulation. The layer pressures are numerically simulated by using the unsteady Bernoulli equation together with the time history of external pressures on the roof. The net wind forces on the PV panels are provided by the difference between the wind pressure on the upper surface and the layer pressure. The simulation is verified by comparing the simulated results of the layer pressures with those obtained from the wind tunnel experiment for the square-roof model. Then, the simulation is applied to the hip-roof building model in Section 5. The wind force coefficients of PV panels installed all over the roof are evaluated. The results indicate that negative wind force coefficients large in magnitude are induced on the PV panels located near the roof corner. However, the magnitude of such negative wind force coefficients decreases with an increase in the gap between PV panels up to approximately $5 \mathrm{~mm}$. When PV panels are installed on the roof, the external pressures on the roofing are equal to the layer pressures. It is found that the peak external pressures on the roofing are significantly reduced in magnitude by the PV panels. Finally, Section 6 summarizes the main conclusions obtained in the present study. 